\title{
Radiotherapy: Impact of Quality of Life and Need for Psychological Care: Results of a Longitudinal Study
}

\author{
S. Sehlen ${ }^{a}$ \\ H. Hollenhorst ${ }^{a}$ \\ B. Schymura ${ }^{\mathrm{a}}$ \\ R. Song ${ }^{a}$ \\ U. Aydemir ${ }^{b}$ \\ N. v. Steinbüchel ${ }^{\mathrm{c}}$ \\ E. Dühmke ${ }^{a}$
}

${ }^{a}$ Klinik und Poliklinik für Strahlentherapie und Radioonkologie, und

${ }^{b}$ Institut für Biometrie und Epidemiologie, Klinikum Großhadern, Ludwig-Maximilians-Universität, München

c Institut für Medizinische Psychologie, Ludwig-Maximilians-Universität, München

Key Words

Quality of life · Radiotherapy · Psychooncology

\section{Summary}

Background: In the framework of a prospective longitudinal study, the quality of life (QoL) and support requirements of patients from a university hospital department of radiotherapy were evaluated for the first time by means of established psychodiagnostic questionnaires. Patients and Methods: At first, 732 patients were screened, of whom $446(60.9 \%)$ fulfilled the criteria for inclusion; $39.1 \%$ did not (refusals $210 \%$, low Karnofsky performance status $6.6 \%$, management problems $3.4 \%$, language barriers $3.0 \%$, cognitive restrictions $2.6 \%$, death $2.5 \%$ ). Disease-specific aspects of QoL (Functional Assessment of Cancer Treatment - General, FACT-G) and moderating variables [Social Support Scale (SSS), Disease Coping (FKV), Self-Assessment Depression Scale (SDS), and Self-Defined Care Requirements (BB)] were selfrated by patients with different tumor types before radiotherapy (T1), after radiotherapy (T2), and 6 weeks after the end of radiotherapy (T3). We studied 265 patients (157 male, 108 female; median age 58.6 years) with complete data of three time points. Results: In general, QoL of patients decreased significantly over all time points in all subscales. Social support was rated high and remained constant throughout the treatment. Apparent coping mechanisms were active problem-oriented coping, leisure activities, and self-support. The patients' depression proved to be an important and constant factor without significant changes. The support requirement is characterized by the need for more medical information and dialogue with a physician. Conclusions: Early specific support from personnel with radiotherapeutic skills, during the disease-coping process as well as during rehabilitation, should be a permanent component of an integrated radiooncological treatment schedule.

\author{
Schüsselwörter \\ Lebensqualität · Radiotherapie · Psychoonkologie
}

\section{Zusammenfassung}

Hintergrund: Im Rahmen einer prospektiven Longitudinalstudie wurden auf der Grundlage von etablierten Instrumenten der Psychodiagnostik erstmalig systematisch die Lebensqualität (QoL) und der Betreuungsbedarf von Patienten einer strahlentherapeutischen Universitätsklinik evaluiert. Patienten und Methodik: 732 Patienten wurden vorläufig in die Studie aufgenommen; davon erfüllten $446(60,9 \%)$ die Einschlußkriterien, 39,1\% nicht (Ablehnung 21,0\%, niedriger KarnofskyStatus $6,6 \%$, organisatorische Probleme $3,4 \%$, Sprachbarrieren 3,0\%, kognitive Einschränkung 2,6\%, Tod 2,5\%). Krankheitsspezifische Aspekte der QoL («Functional Assessment of Cancer Treatment, General», FACT-G) und Moderator-Variablen [«Social Support Score» (SSS, soziale Unterstützung), «Self-Rating Depression Scale» (SDS, Depressionsskala), «Freiburger Fragebogen zur Krankheitsverarbeitung (FKV) und selbstdefinierter «Betreuungsbedarf» (BB)] wurden zu Beginn (T1), am Ende der Strahlentherapie (T2) und 6 Wochen nach Strahlentherapie (T3) abgefragt. 265 Patienten mit unterschiedlichen Tumorerkrankungen (157 Männer, 108 Frauen; medianes Alter 58,6 J ahre) und kompletten Daten zu T1-T3 nahmen an der Untersuchung teil. Ergebnisse: Eine signifikante Abnahme der Lebensqualität wurde zu allen Untersuchungszeitpunkten in allen Subskalen beobachtet. Die erlebte soziale Unterstützung war über alle Erhebungszeitpunkte hinweg hoch. Ausgeprägte Krankheitsverarbeitungsmechanismen sind «aktives problemorientiertes Coping» sowie «Ablenkung und Selbstaufbau». Depression bei Patienten erwies sich als wichtiges und konstantes Merkmal über den gesamten Untersuchungszeitraum hinweg. Der Betreuungsbedarf wurde bestimmt durch den Wunsch nach mehr Sachinformation und nach Gesprächen mit einem Arzt. Schlußfolgenungen: Frühzeitige spezifische Unterstützung im Krankheitsverarbeitungsprozess und in der Rehabilitationsphase durch Personal mit strahlentherapeutischen Fachkenntnissen sollte fester Bestandteil eines integrativen radioonkologischen Behandlungskonzeptes sein.

\begin{tabular}{ll}
\hline KARGER & ○ 2000 S. Karger G mbH , Freiburg \\
Fax +49 761 4520714 & A ccessible online at: \\
$\begin{array}{l}\text { E-mail Information@K arger.de } \\
\text { www.karger.com }\end{array}$ & www.karger.com/journals/onk \\
&
\end{tabular}

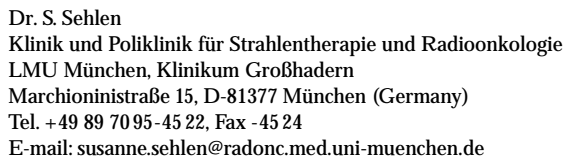




\section{Introduction}

The health-related quality of life $(Q \mathrm{oL})$ of tumor patients has become more and more important during the last years because of optimized treatment schedules and the resulting increased survival rate. A part from physical symptoms and the ability to function in daily life, psychosocial factors are also of crucial importance for the patients' Q oL. H ealth-related Q oL is a multidimensional construct that should be assessed by measuring the functioning and well-being of a patient in the following dimensions: physical, emotional and mental, social and daily life [1]. Besides this also psychosocial and emotional aspects are of crucial importance for patients. In contrast to clinical research up to now, the aim of our investigation is to describe main factors of $\mathrm{Q} O \mathrm{~L}$ and moderating variables for cancer patients receiving radiotherapy. Of special interest are the influence of radiooncological treatment on well-being and the resulting care requirements. During radiotherapy, in addition to psychosocial distress related to cancer, patients suffer the consequences of stressful treatment. Typical side effects of radiotherapy were observed: among others, tiredness, decrease in appetite, nausea and depression. A Iso phsychological side effects such as anxiety about the dimension of radiotherapeutic devices, isolation of therapy rooms, and the fear of being at the mercy of invisible radiation energy and of the medical personnel administering treatment were observed [2].

Results of clinical studies which evaluate relevant aspects of the $\mathrm{Q}$ oL of patients under radiotherapy are available only to a limited extent [3-6].

The aim of this study, therefore, is to investigate extensive longitudinal data based on established, psychometric instruments of psychodiagnosis in order to evaluate the $\mathrm{QoL}$ influenced by radiation of patients. O ur intention was to verify whether the expected decrease of $\mathrm{Q} o \mathrm{~L}$ was observed and whether it resulted in lower $\mathrm{Q}$ oL of radiation-treated patients in comparison with other tumor patients or patients with chronical disease. The influence on psychosocial well-being and requirement for care was of special interest.

\section{Patients and Methods}

D isease-specific aspects of $Q \mathrm{OL}$ and moderating variables were self-rated by patients with different tumor types before radiotherapy (T1), after radiotherapy (T2), and 6 weeks after the end of radiotherapy (T3). Completion of assessment tables took between 20 and 40 min. Radiotherapyinduced changes in $\mathrm{Q} o \mathrm{~L}$ and moderating variables were calculated over the assessment points. Generally, 6 weeks after radiotherapy acute side effects are observed, and an improvement of $Q \mathrm{oL}$ in general or statisfaction with $\mathrm{Q}$ oL was expected. The following instruments were utilized:

\section{Q uality of L ife Instruments}

Functional A ssessment of Cancer Treatment - G eneral (FACT-G), Version 3 [7]

For general insight in the disease-specific aspects of $\mathrm{Q}$ oL of tumor patients the Functional A ssessment of Cancer Treatment (FACT) was developed. The FACT-G count of five subscales evaluating physical, social/family, emotional and functional well-being and the patient's relationship with doctors was analyzed. These various $\mathrm{Q}$ oL domains were assessed as a function of treatment with 29 items; each item scored on 1-5 categories.
M oderating Variables

Important variables moderating the $\mathrm{Q}$ oL of patients under radiotherapy are the following:

Social Support Scale (SSS) [8]

Registers the perceived social support with 20 items, divided into three subscales (cognitive, emotional, practical), and is self-rated by the patients.

Freiburg Q uestionnaire Coping with the Disease (Freiburger Fragebogen zur K rankheitsverarbeitung, FK V) [9]

$M$ easurement of different coping strategies on the basis of 35 items in five subscales (active problem-oriented coping, distractions, spirituality, minimizing importance, depressive coping).

Self-A ssessment D epression Scale (SD S) [10]

Symptoms of depression (20 items), allocated to four subscales, are evaluated by the patients.

Care R equirements (B etreuungsbedarf, B B ), Self-D eveloped Instrument Patient's self-assessment to quantify the need of psychosocial support by third persons as well as care requirements: 9 categories (psychosocial support by doctor/psychotherapist, hospital chaplain, information, other patients, self-help groups, change of job/retraining, pension, nursing care).

Statistics

Statistical evaluations were carried out with $\mathrm{SPSS}^{\circ}$. R epeated measurements of variance were analyzed at time points T1, T2 and T3 with MA NOVA (multiple analysis of variance).

\section{Results}

From November 1997 to M ay 1999, 732 patients in the department of radiotherapy at Klinikum Grosshadern, Ludwig M aximilian U niversity, M unich, were screened for the study. Of these, 446 patients (60.9\%) fulfilled the criteria for inclusion; $39.1 \%$ did not (refusals $21.0 \%$, low Karnofsky performance status $6.6 \%$, management problems $3.4 \%$, language barriers $3.0 \%$, cognitive restrictions $2.6 \%$, death $2.5 \%$ ). In 265 patients complete psychometric and clinical data of T 1-T 3 was collected (table 1).

First we are describing results of investigations of different concepts of Q oL. In general, the Q oL of patients decreased significantly over the assessment points in all subscales with exception of functional well-being (table 2). The physical wellbeing decreased at the end of therapy with a slight increase 6 weeks after radiotherapy, not reaching baseline quality $(p<0.001)$. E motional well-being $(p=0.030)$, relationship to family/friend $(p<0.001)$, and relationship to doctor $(p<0.001)$ continuously decreased to $T 3$. These tendencies were also shown in the total score $(p<0.001)$.

The social support of tumor patients under radiotherapy as a moderator variable of $\mathrm{QOL}$ was rated relatively high with a score of 4.23-4.27 on a scale from 1 to 5 ; the mean showed no difference between the three subscales and over the course of the investigation.

In the course of the investigation the most prominent coping mechanisms of the patients showed to be active problem-oriented coping and distractions. D epressive coping mechanisms, 
Table 1 M edical and sociodemographic data of 265 patients with complete T1-T 3 data

\begin{tabular}{|c|c|c|}
\hline \multirow[t]{2}{*}{$\begin{array}{l}\text { A ge, years } \\
\text { M edian } \\
\text { R ange }\end{array}$} & \multicolumn{2}{|c|}{$\begin{array}{l}58.6 \\
19-93\end{array}$} \\
\hline & $n$ & $\%$ \\
\hline$<45$ & 47 & 17.7 \\
\hline $45-\leq 60$ & 94 & 35.5 \\
\hline$>60$ & 124 & 46.8 \\
\hline \multicolumn{3}{|l|}{ Gender } \\
\hline Female & 108 & 40.8 \\
\hline Male & 157 & 59.2 \\
\hline M edical data & $\mathrm{n}$ & $\%$ \\
\hline \multicolumn{3}{|l|}{ Diagnosis } \\
\hline M amma carcinoma & 57 & 21.5 \\
\hline U rogenital tumor & 44 & 16.6 \\
\hline G astrointestinal tumor & 34 & 12.8 \\
\hline $\mathrm{H}$ ead/neck cancer & 34 & 12.8 \\
\hline Lymphoma & 34 & 12.8 \\
\hline Lung cancer & 19 & 7.2 \\
\hline Brain tumor & 16 & 6.0 \\
\hline Soft- tissue sarcoma & 10 & 3.8 \\
\hline Other & 17 & 6.5 \\
\hline \multicolumn{3}{|l|}{ T status ${ }^{\mathrm{a}}$} \\
\hline T1 & 46 & 17.4 \\
\hline $\mathrm{T} 2$ & 62 & 23.4 \\
\hline T3 & 40 & 15.1 \\
\hline T4 & 32 & 12.1 \\
\hline$T x$ & 28 & 10.6 \\
\hline \multicolumn{3}{|l|}{ N status ${ }^{\mathrm{a}}$} \\
\hline NO & 77 & 29.1 \\
\hline N1 & 58 & 21.9 \\
\hline N2 & 29 & 10.9 \\
\hline N3 & 4 & 1.5 \\
\hline $\mathrm{Nx}$ & 40 & 15.1 \\
\hline \multicolumn{3}{|l|}{ M status } \\
\hline MO & 137 & 51.7 \\
\hline M 1 & 40 & 15.1 \\
\hline$M x$ & 31 & 11.7 \\
\hline Sociodemographic data & $\mathrm{n}$ & $\%$ \\
\hline \multicolumn{3}{|l|}{ Karnofsky index } \\
\hline$\geq 90$ & 172 & 64.9 \\
\hline$<90$ & 93 & 35.1 \\
\hline \multicolumn{3}{|l|}{ Partner } \\
\hline Yes & 189 & 80.8 \\
\hline No & 45 & 19.2 \\
\hline \multicolumn{3}{|l|}{ Children } \\
\hline Yes & 201 & 77.3 \\
\hline No & 59 & 22.7 \\
\hline \multicolumn{3}{|l|}{ Family status } \\
\hline Single & 36 & 13.6 \\
\hline$M$ arried & 191 & 72.1 \\
\hline Separated, divorced or widowed & 38 & 14.3 \\
\hline
\end{tabular}

minimizing the importance of disease, and wishful thinking played a less important role. A significant decrease from T1 to T3 was seen in active problem-oriented coping mechanisms ( $p$ $<0.001$ ) (fig. 1).
The patients' depression proved to be an important and constant factor without significant changes during treatment (T 1 and T2) and after therapy (T3). The mean score on a scale from 0 to 50 was $36.8-37.5$.

Care R equirements ( $B \mathrm{~B}$ )

During the course of the investigation, patients showed an above-average need for further information about treatment options and side effects and for support from a doctor or psychotherapist. U p to 6 weeks after radiotherapy patients formulated a limited need of occupational support, advice about home nursing, and psychological support from a hospital chaplain (table 3).

$\mathrm{H}$ igh levels of health-related $\mathrm{Q}$ oL correlated with high scores of social support and low levels of depression. Coping mechanisms of these patients were less depressive and showed less minimizing of importance of disease than those of patients with low levels of health-related QoL. Despite a high $\mathrm{QoL}$ there was a positive correlation with need of care requirements (table 4).

\section{Discussion}

We investigated a heterogeneous sample of cancer patients to study the specific effects of radiotherapy on patients with tumor diseases with respect to medical aspects, their $\mathrm{Q} o \mathrm{~L}$ and moderator variables of $\mathrm{Q} \mathrm{oL}$.

O ur study showed values similar to those of Cella et al. [7], who investigated a comparable heterogeneous sample of tumor patients: I n contrast to general expectations, a decrease of $\mathrm{Q}$ oL by radiotherapy was not observed. In the physical well-being component, a decrease of $\mathrm{Q}$ oL was observed at $\mathrm{T} 2$ due to side effects with an expected increase of $\mathrm{Q} O \mathrm{~L}$ at $\mathrm{T} 3$, these results being comparable to those of other authors $[6,11,12]$.

A spects of emotional well-being and relationship to family and friends decreased at T 3; at this time point, also a lack of daily support and treatment by medical staff became obvious. In fact, this seems to be a general problem of patients with chronic diseases.

Tumor patients under and after radiotherapy with a high level of $Q \mathrm{oL}$ had a high score of social support, good coping mechanisms (active problem-oriented coping and distractions), more care requirements (information), and a low score of depression. O ne moderator variable of $\mathrm{Q}$ oL is social support measured with the SSS. Social support is an important mechanism of protection against psychological stress of patients in dealing with tumor disease [13], and can have a positive influence on the rehabilitation of these patients. Social support also has an effect on survival depending on the type and spread of disease [14]. In 181 cancer patients under radiotherapy, I rwin et al. [15] were able to show a significant decrease in anxiety and depression after completion of therapy. In our study, the depression scores remained constant throughout the course of treatment. Whether this could be interpreted as a disturbed ability to cope with the disease or whether the therapy and its side effects may have had an impact on coping and the perceived intensive distress which normally accompanies malignant disease $[16,17]$ is still an open question. D epressed patients receiving radiotherapy 
Table 2. Functional assessment of cancer treatment (FACT-G) and total values at defined time points $T 1, T 2$ and $T 3(n=265)$
Fig. 1 Coping with cancer (FKV) subscales at defined dates T1 $(\square), T 2(\square)$ and T3 $(n=265)$.

Table 3. Subscales of care requirements and total values at defined time points $T 1, T 2$ and T $3(n=265)$

\begin{tabular}{|c|c|c|c|c|c|c|c|}
\hline & \multicolumn{2}{|l|}{$\mathrm{T} 1$} & \multicolumn{2}{|l|}{ T2 } & \multicolumn{2}{|l|}{ T3 } & \multirow{2}{*}{$\begin{array}{l}\text { Significance } \\
\mathrm{p}\end{array}$} \\
\hline & $M$ & SD & $M$ & SD & $M$ & SD & \\
\hline $\begin{array}{l}\text { Physical well-being } \\
\text { (range } 0-28 \text { ) }\end{array}$ & 20.5 & 5.6 & 19.2 & 6.3 & 20.5 & 6.0 & $<0.001$ \\
\hline $\begin{array}{l}\text { Social/family } \\
\text { (range } 0-28 \text { ) }\end{array}$ & 21.0 & 4.5 & 20.3 & 4.4 & 19.9 & 4.3 & $<0.001$ \\
\hline $\begin{array}{l}\text { D octors } \\
\quad \text { (range } 0-8)\end{array}$ & 6.6 & 1.4 & 6.3 & 1.5 & 6.2 & 1.5 & $<0.001$ \\
\hline $\begin{array}{l}\text { E motional well-being } \\
\text { (range } 0-20)\end{array}$ & 14.8 & 3.8 & 14.7 & 3.8 & 14.4 & 4.0 & 0.030 \\
\hline $\begin{array}{l}\text { Functional well-being } \\
\text { (range } 0-28 \text { ) }\end{array}$ & 17.2 & 5.4 & 17.1 & 5.5 & 17.2 & 5.5 & n.s. \\
\hline $\begin{array}{l}\text { Total score } \\
\text { (range } 0 \text { - 112) }\end{array}$ & 80.2 & 14.7 & 77.8 & 15.1 & 78.4 & 15.9 & 0.001 \\
\hline
\end{tabular}

$\mathrm{M}=\mathrm{M}$ ean value; $\mathrm{SD}=$ standard deviation; $\mathrm{n} . \mathrm{S}$ = not significant.

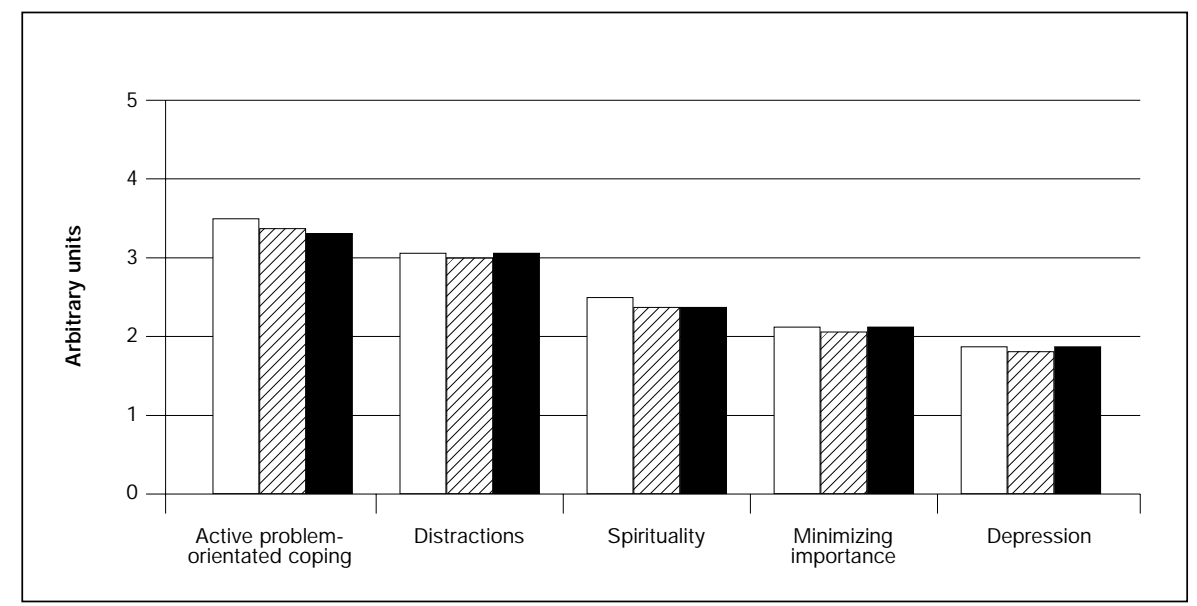

\begin{tabular}{|c|c|c|c|c|c|c|c|}
\hline \multirow[t]{2}{*}{ Care requirements } & \multicolumn{2}{|l|}{$\mathrm{T} 1$} & \multicolumn{2}{|l|}{ T2 } & \multicolumn{2}{|l|}{ T3 } & \multirow{2}{*}{$\begin{array}{l}\text { Significance } \\
p\end{array}$} \\
\hline & $\bar{M}$ & SD & $\bar{M}$ & $\overline{S D}$ & $\bar{M}$ & $\overline{S D}$ & \\
\hline \multicolumn{8}{|l|}{ Psychosocial support } \\
\hline Doctor & 2.4 & 1.3 & 2.2 & 1.3 & 2.5 & 1.3 & 0.004 \\
\hline Psychotherapist & 2.1 & 1.4 & 2.1 & 1.4 & 2.1 & 1.3 & n.s. \\
\hline H ospital chaplain & 1.6 & 0.9 & 1.7 & 1.0 & 1.7 & 1.0 & n.s. \\
\hline Information & 3.7 & 1.3 & 3.5 & 1.3 & 3.4 & 1.4 & 0.023 \\
\hline Other patients & 2.0 & 1.3 & 2.0 & 1.3 & 2.0 & 1.3 & n.s. \\
\hline Self-help group & 1.9 & 1.2 & 1.9 & 1.2 & 1.7 & 1.1 & 0.011 \\
\hline Change of job / retraining & 1.5 & 1.0 & 1.4 & 0.9 & 1.5 & 1.0 & n.s. \\
\hline Pension & 1.8 & 1.4 & 1.9 & 1.3 & 1.9 & 1.4 & n.s. \\
\hline Nursing care & 2.0 & 1.4 & 1.7 & 1.2 & 1.8 & 1.3 & 0.020 \\
\hline
\end{tabular}

$M=M$ ean value; $S D=$ standard deviation; $n . S .=$ not significant. should be identified and offered psychological and medical support [18]. Through appropriate support a better compliance, fewer side effects, and more successful rehabilitation may be achieved. In the context of coping with their disease, patients are confronted with fear, worry, and grief. R eactions to therapy may become pervasive or cause distress. Eventually, patients may develop acute anxiety or depression requiring treatment [19]. The positive effect of increased Q oL on survival is 
Table 4. Correlation of Q oL instrument FACT-G with moderating variables Social Support Scale SSS, Coping with Disease FK V, Self-A ssessment D epression Scale SDS, and Care Requirements B B

\begin{tabular}{|c|c|c|c|c|c|c|c|c|c|c|c|c|c|}
\hline & & \multicolumn{5}{|l|}{ FKV } & \multirow{2}{*}{$\begin{array}{l}\text { SSS } \\
\text { total } \\
\text { score }\end{array}$} & \multirow{2}{*}{$\begin{array}{l}\text { SDS } \\
\text { total } \\
\text { score }\end{array}$} & \multicolumn{5}{|l|}{ BB } \\
\hline & & $\begin{array}{l}\text { active } \\
\text { problem } \\
\text { oriented }\end{array}$ & $\begin{array}{l}\text { dis- } \\
\text { traction }\end{array}$ & $\begin{array}{l}\text { mini- } \\
\text { mizing } \\
\text { impor- } \\
\text { tance }\end{array}$ & $\begin{array}{l}\text { depres- } \\
\text { sion }\end{array}$ & $\begin{array}{l}\text { spiri- } \\
\text { tuality }\end{array}$ & & & doctor & $\begin{array}{l}\text { infor- } \\
\text { mation }\end{array}$ & $\begin{array}{l}\text { patient } \\
\text { group }\end{array}$ & $\begin{array}{l}\text { psycho- } \\
\text { therapist }\end{array}$ & $\begin{array}{l}\text { self- } \\
\text { help } \\
\text { group }\end{array}$ \\
\hline \multirow{2}{*}{$\begin{array}{l}\text { FACT } \\
\text { Family }\end{array}$} & \multirow{2}{*}{$\begin{array}{l}\text { Pearson correlation } \\
\text { significance } \\
n\end{array}$} & 0.107 & 0.064 & -0.150 & -0.173 & 0.063 & 0.379 & -0.272 & 0.078 & -0.016 & 0.073 & 0.011 & -0.025 \\
\hline & & 0.087 & 0.303 & 0.017 & 0.005 & 0.317 & 0.000 & 0.000 & 0.218 & 0.805 & 0.251 & 0.868 & 0.690 \\
\hline \multirow{3}{*}{$\begin{array}{l}\text { FACT } \\
\text { Doctor }\end{array}$} & \multirow{3}{*}{$\begin{array}{l}\text { Pearson correlation } \\
\text { significance } \\
n\end{array}$} & 0.038 & -0.025 & 0.012 & -0.216 & -0.019 & 0.297 & -0.198 & 0.051 & 0.049 & 0.047 & 0.104 & 0.074 \\
\hline & & 0.543 & 0.689 & 0.857 & 0.001 & 0.767 & 0.000 & 0.003 & 0.431 & 0.442 & 0.469 & 0.102 & 0.249 \\
\hline & & 255 & 255 & 248 & 255 & 254 & 252 & 221 & 245 & 246 & 244 & 246 & 246 \\
\hline \multirow{3}{*}{$\begin{array}{l}\text { FACT } \\
\text { E motional }\end{array}$} & \multirow{3}{*}{$\begin{array}{l}\text { Pearson correlation } \\
\text { significance } \\
n\end{array}$} & -0.140 & -0.163 & -0.300 & -0.672 & -0.092 & 0.120 & -0.620 & 0.154 & 0.063 & 0.217 & 0.282 & 0.188 \\
\hline & & 0.024 & 0.009 & 0.000 & 0.000 & 0.139 & 0.055 & 0.000 & 0.016 & 0.319 & 0.001 & 0.000 & 0.003 \\
\hline & & 259 & 259 & 252 & 259 & 258 & 256 & 224 & 247 & 249 & 247 & 248 & 249 \\
\hline \multirow{3}{*}{$\begin{array}{l}\text { FACT } \\
\text { Functional }\end{array}$} & \multirow{3}{*}{$\begin{array}{l}\text { Pearson correlation } \\
\text { significance } \\
n\end{array}$} & 0.008 & 0.071 & -0.127 & -0.362 & 0.018 & 0.228 & -0.722 & 0.156 & 0.065 & 0.203 & 0.077 & 0.148 \\
\hline & & 0.894 & 0.253 & 0.043 & 0.000 & 0.769 & 0.000 & 0.000 & 0.014 & 0.309 & 0.001 & 0.228 & 0.019 \\
\hline & & 260 & 260 & 253 & 260 & 259 & 256 & 225 & 248 & 249 & 248 & 249 & 250 \\
\hline \multirow{3}{*}{$\begin{array}{l}\text { FACT } \\
\text { Total score }\end{array}$} & \multirow{3}{*}{$\begin{array}{l}\text { Pearson correlation } \\
\text { significance } \\
n\end{array}$} & -0.031 & -0.054 & -0.259 & -0.560 & -0.078 & 0.321 & -0.785 & 0.188 & 0.094 & 0.252 & 0.194 & 0.191 \\
\hline & & 0.631 & 0.397 & 0.000 & 0.000 & 0.219 & 0.000 & 0.000 & 0.004 & 0.147 & 0.000 & 0.003 & 0.003 \\
\hline & & 249 & 249 & 243 & 249 & 248 & 245 & 216 & 240 & 240 & 239 & 240 & 241 \\
\hline
\end{tabular}

still discussed controversially. Ringdal et al. [20] described the predominance of disease-related factors whereas, in their opinion, psychosocial factors have only modulating influence. A n active problem-oriented coping style and low emotional distress may positively influence survival by improving compliance with medical treatment [21].

While, to a large extent, acute psychological reactions to the diagnosis were similar in most patients, each developed his/her individual coping pattern. It was therefore of great importance to identify those factors in patients indicating a good or bad coping strategy [22], which would make it possible to select appropriate therapies in the future. In the course of our study, coping strategies of patients who received radiotherapy remained relatively stable. M ost common were active problemoriented coping, distraction and self-help; only problemoriented coping decreased significantly $(p<0.001)$. Social withdrawal seems to play a significant role; this behavior is interpreted as a specific coping reaction to cancer with the aim of self-stabilization. In the opinion of psychooncologists there is a pressing need for psychosocial care [23, 24]. $0 \mathrm{n}$ the other hand, there is a low acceptance of established psychosocial care [25]. There is no doubt that clinical indications for psychosocial care are more abvious to medical personnel than to the patients themselves. Nevertheless, a professional intervention must be applied with care to avoid endangering the mental stability of the patient. D istraction and self-help, as well as suppression are phase-specific coping mechanisms, which should not be used forcibly.
In our study the greatest need for psychosocial care evolves during the period up to 6 weeks after completion of radiotherapy; particularly, there is need for additional information about therapies and side effects as well as about psychological care and counseling from the doctors' side. In contrast to findings in the literature this points to active problemoriented coping with cancer and its treatment as well as with psychosocial problems observed specifically in radiotherapy patients.

In an investigation of A nnunziata et al. [26], well-informed patients were not more content with medical and psychosocial care than less well-informed patients. A higher rate of life satisfaction was evident in patients who were content with the type of information received, whether or not they belonged to the group of well-informed or less well-informed patients.

There is no doubt that accompanying psychosocial care of radiooncology patients does support the process of adaptation to disease and improve life satisfaction. Cunningham at al. [27] investigated a manualized treatment modality with supportive expressive group psychotherapy for patients and their relatives and assessed it as cost-effective and helpful to improve QoL.

E arly and adequate rehabilitation is the aim. Patients ask for additional information about the disease and for opportunity to discuss psychological problems with a doctor, they and prefer patient-centered communication [28]. B oth disease and therapy require health professionals who have relevant qualifications and expertise in radiotherapy and psychooncology. 


\section{References}

1 Bullinger $\mathrm{M}, \mathrm{H}$ asford $\mathrm{J}$ : Evaluating quality of life measures for clinical trials in Germany. Control Clin Trials 1991;12:915-1055

2 Schlömer U: Psychologische Unterstützung in der Strahlentherapie. Wien, Springer, 1994.

3 Frischenschlager $O$, Hohenberg $G, H$ exel $M$, Kropiunigg $\mathrm{U}, \mathrm{H}$ andl-Zeller $\mathrm{L}$ : Psychosoziale $\mathrm{Be}$ treuung radioonkologischer Patienten - B edarf, subjektives Bedürfnis und A kzeptanz. Strahlenther O nkol 1992;168:53-57.

$4 \mathrm{~L}$ angendijk $\mathrm{H}, \mathrm{A}$ aronson NK, De Jong JMA, ten Velde GPM, M uller MJ, Wouters M : The prognostic impact of quality of life assessed with the EORTC QLQ-C30 in inoperable non-small cell lung carcinoma treated with radiotherapy. Radiother $\mathrm{O}$ ncol 2000:55:19-25.

$5 \mathrm{Liu} \mathrm{Li}$, Meers $\mathrm{K}$, Capurso A, Engebretson TO, Glicksman A S: The impact of radiation therapy on quality of life in patients with cancer. Cancer Pract 1998;6:237-242.

6 W helan T, L levine M, Julian J, K rikbridge P, Skingley $P:$ The effects of radiation therapy in quality of life of women with breast cancer. R esults of a randomized trial. Cancer 2000;88:2260-2266.

7 Cella DF, Tulsky DS, Gray G, Sarafia B, Linn E B onomi A : Functional assessment of cancer therapy scale: Development and validation of the general measure. J Clin O ncol 1993;11:570-579.

8 Sherbourne CD, Hays RD: Marital status, social support and health transitions in chronic disease patients. H ealth Soc B ehav 1990;31:328-343.

9 M uthny FA : Freiburger Fragebogen zur K rankheitsverarbeitung, FK V. Weinheim, B eltz, 1990.
10 Zung WK: Factors influencing the Self-R ating Depression Scale. A rch Gen Psychiatry 1976;16: 543-547.

11 B lazeby J M , Farndon J R, D onovan J, A Iderson D : A prospective longitudinal study examining quality of life patients with esophageal carcinoma. Cancer 2000;88:1781-1787.

12 Lev EL, Paul D, O wen SV: A ge, self-efficacy, and change in patients adjustment to cancer. Cancer Practice 1999;7:170-176.

13 I rvine D, B rown B, Crooks D, R oberts ], B rowne G : Psychosocial adjustment in women with breast cancer. Cancer 1991;67:1097-1117.

14 Thoits P: Social Support as coping assistance. I Consult Clin Psychol 1986:54:416-423.

15 I rwin PH , K ramer S, D iamond NH , M alone D, Z ivin $G$ : Sex differences in psychological distress during definitive radiation therapy for cancer. J Psychosoc Oncol 1986;4:63-75

16 Beutel M, Muthny FA : Konzeptualisierung und klinische Erfassung von K rankheitsverarbeitung $\mathrm{H}$ intergrundstheorien, $\mathrm{M}$ ethodenprobleme und künftige Möglichkeiten. Psychother Psychosom Med Phsychol 1988;38:19-27.

17 Silverstone PH : D epression increases mortality and morbidity in acute life-threatening medical illness J Psychosom R es 1990;34:651-657.

18 Sellick SM , Crooks D L : D epression and cancer: A n appraisal of the literature for prevalence, detection and practice guideline development for psychological interventions. Psychooncology 1999;8:315-333.

19 Fawzy FI: A short-term psychoeducational intervention for patients newly diagnosed with cancer. Support Care Cancer 1995:3:235-238.
20 R ingdal G I, G ötestam K G, K aasa S, K vinnsland S, $R$ ingdal $K$ : Prognostic factors and survival in a heterogeneous sample of cancer patients. $\mathrm{Br}$ J Cancer 1996;73:1594-1599.

21 Faller $\mathrm{H}$ : D o psychological factors modify survival of cancer patients? I. R eview of the literature. Psychother Psychosom M ed Psychol 1997;47:163-169.

$22 \mathrm{H}$ eim $\mathrm{E}$ : C oping and A daptivität: $\mathrm{G}$ ibt es geeignetes und ungeeignetes Coping? Psychother Psychosom M ed Psychol 1988;38:8-18.

23 Schwarz R : B edarf an psychosozialer B etreuung von $K$ rebskranken und $A$ nforderungen an die psychosoziale Personalfortbildung; in Koch U, Patrick Rose $\mathrm{F}$ ( $\mathrm{H} \mathrm{rsg})$ : K rebsrehabilitation und Psychoonkologie. Berlin, Springer, pp 124-133.

24 Koch P: Psychoonkologie in Deutschland. Psycho ther Psychosom M ed Psychol 1998;48:319-320.

$25 \mathrm{H}$ erschbach P: Stationäre onkologische R ehabilitation - eine B edarfsanalyse. Z personenzentr Psycho Psychother 1987;1:31-45.

26A nnunziata M A, Foladore S, M agri MD, Crivellari $D$, Feltrin $A$, Bidoli $E$, Veronesi $A$ : Does the in formation level of cancer patients correlate with quality of life? A prospective study. Tumori 1998; 84:619-623.

27 Cunningham AJ, Edmonds CV, Williams D: Delivering a very brief psychoeductional program to cancer patients and family members in a large group format. Psychooncology 1999;8:177-182.

28 D owsett SM, Saul J L, B utow PN, D unn SM, B oye MJ, Findlow R: Communication styles in the cance consultation: Preferences for a patient-centered approach. Psychooncology 2000;9:147-156. 